\title{
不連続性基盤の応力, 変形および破壊に関する模型実験*
}

\author{
山本 和 夫** 有 岡 正 樹*** \\ Model Experiments on Stress Distribution, Deformation \\ and Fracture in the Discontinuous Rock Foundation
}

by

Kazuo Yamamoto and Masaki ARIOKA

(Faculty of Engineering, Kyoto University, Kyoto)

\begin{abstract}
The mechanical behavior of rock mass under load is influenced by the nature of discontinuous geological planes rather than that of rock material itself.

Model tests were made with idealized models with discontinuous planes orientated vertically and horizontally.

The results obtained are as follows : stress distribution shows concentration along the vertical central axis of the loading plate. The state of fractures is different from that of the homogeneous and isotropic elastic solid. Cracks are initiated either by partial tension or partial shear, and then they are propagated toward lower parts of the foundation.

Hence it is necessary to examine sufficiently the nature of discontinuous planes involved, in order to understand the characteristics of such discontinuous rock foundation.
\end{abstract}

(Received June 13, 1968)

\section{1 緒言}

岩盤の力学的強度は, 構成する岩石そのものの強度 よりむしろ岩盤内に存在する地質学的分離面の状態に 影響される。したがって岩石自身の力学的性質を知る と同時に分離面をも含めた不連続体としての力学的性 質を知らねばならない. しかしこれらの分離面（以下 不連続面と呼ぶ）の状態が及ぼす影響は多様であり，

複雑な実在岩盤の応力拈よび変形状態や安定性を直接 解明することは困難である。したがって, 従来から現 場に执いて岩盤試験を行ならとともに, 影響の及ぼす 要素のあるものを取り出し理想化した岩盤の力学的模 型により室内試験を行なっている.

本研究では, 不連続面が縦と横に規則正しくはいっ ている模型（以下不連続性基盤と呼ぶ）を考光，その 力学的挙動を実験的に把握することを目的としている. この種のブロックの積重衩の模型は Krsmanović らら, Trollope ら口, 林などの研究に和いて子取り扱われて, 定性的実験之簡単な理論的解析が行なわれている。こ こでは岩石のアナロジーとして, アラルダイトBとセ メントモルタルの二つを用いて, 定性的执よび定量的

* 原稿受理 昭和 43 年 6 月 13 日

** 正会員 京都大学工学部 京都市左京区吉田本町

*** 京都大学大学院 京都市左京区吉田本町
な 2 種類の模型実験を行ない，この種の不連続性基盤 の応力, 変形拈よび破壊に対する不連続面の及添す影 響について検討を行なっている。

\section{2 光弹性材料による模型実験}

\section{$2 \cdot 1$ 実験装置と実験方法}

光弾性材料アラルダイトBを岩石のアナロジーとし て用い，不連続面に硬・柔 2 種類の接着材 (以下充て 几物と呼ぶ）で充てんして定性的実験を行なった。前 者のかたい充てん物としてアラルダイト D, 後者の柔 らかい充てん物としてセメダインコンダクトを使用し， いずれの場合も実験は接着24時間後に行なった。実験 に使用したアラルダイトBの性質を Table I に示す. 充てん物のアラルダイトDの弾性倸数は, アラルダイ トBとほぼ等しく約 $30000 \mathrm{~kg} / \mathrm{cm}^{2}$, セメダインコン タクトは非常浊らかく弾性係数は数 $10 \mathrm{~kg} / \mathrm{cm}^{2}$ であ る.

装置は透過式の光弾性装置を使用し, 載荷はアラル ダイトBの載荷板と薄いゴムシートを通して行なっ た。

\section{$2 \cdot 2$ 実験結果および考察}

Fig. 1 (a)，(b)は柔らかい充てん物セメダインコンタ クトを使用した場合の等色線しま模様である。後者は ブロック中心に穴をあけたものである。個々のブロッ 


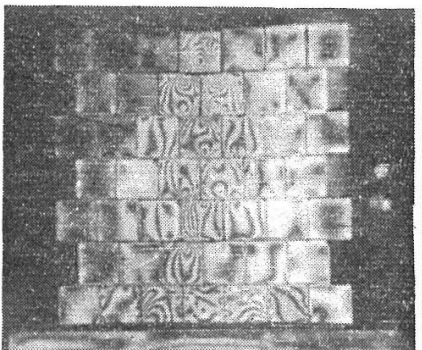

(a) Filled cemedinecontact

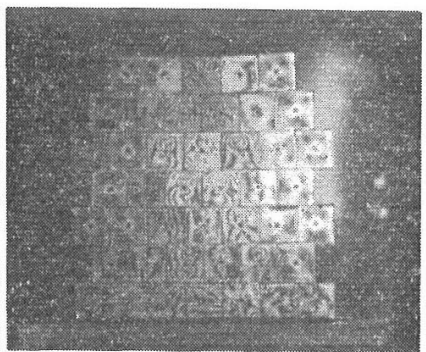

(b) Filled cemedinecontact with small holes

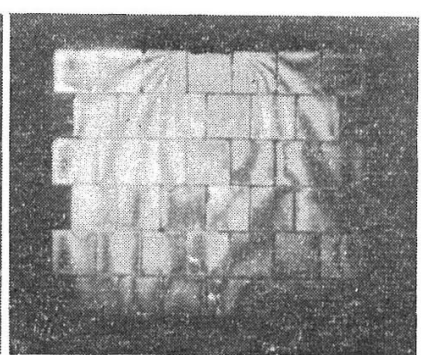

(c) Filled Araldite D

Fig. 1. Photoelastic fringe pattern in Araldite B.

Table I. Properties of Araldite B.

\begin{tabular}{l|c}
\hline Elastic modulus & $29000 \sim 32000 \mathrm{~kg} / \mathrm{cm}^{2}$ \\
Poisson's ratio & $0.35 \sim 0.37$ \\
Stress-fringe value & $10.0 \sim 11.0 \mathrm{~kg} / \mathrm{cm}$ \\
\hline
\end{tabular}

ク端においてかなりの応力集中の現象が認められ，接 着部に执いて応力は不連続である。また, 荷重は側方 へは洼とんど伝達せず載荷面直下に集中している。こ れは充てん物が柔らかいので, 層全体があたかるはり のよらな挙動を示すためである。また，載荷面直下に かなり大きな横方向の引張力が見られ, 荷重の増大と ともにその傾向は著しい。この上うな現象は等方等質 の弾性体に赫いては現わ机ないるのである。したがっ

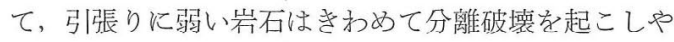
すい状態になるるのと思われ，軟弱な充てん物はそれ を含む基盤全体の強度を弱めることはもちらん，基盤 を構成する岩石の強度をも割引きするような作用をす ることになる。

Fig. 1 (c) はかたい充てん物アラルダイトDを使用 した場合の等色線しま模様である。この場合において は, ブロック端に和ける応力集中の現象, 接着部に扔 ける応力の不連続抢よび層のはりのよらな挙動はいず れも認められず，注洼等方等質体の場合と一致してい る.

この種の光弾性材料などを使用した実験では, 難解 な相似律の問題がつきまとうのは避けがたく, 定性的 籁囲でしか現象をつかめない。したがって，ここでは 次の 3 で述べるセメントモルタル材料による模型実験 の予備として炎の現象を定性的俚解することを目的 とした。

\section{3 セメントモルタル材料による模型実験}

\section{$3 \cdot 1$ 実験装置と実験方法}

ここでは立方体セメントモルタルのブロック岩岩石 のアナロジーとして使用し，不連続面にはセメントペ 一ストを用いて定量的実験を試みた。

Fig. 2 亿実験装置を示す。不連続性基盤模型は $5 \mathrm{~cm}$ 立方のモルタルブロックを厚さ $3 \mathrm{~mm}$ の充てん物セメ

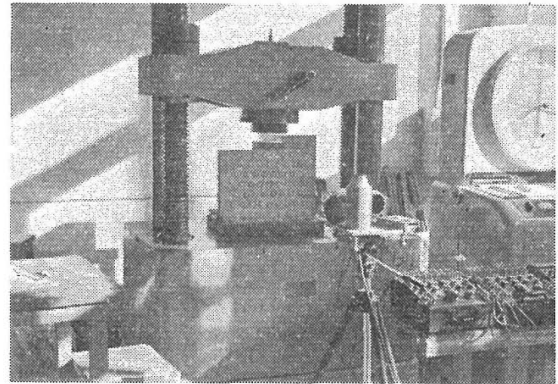

Fig. 2. Testing apparatus.

ントペースト（セメントとフライアシュを水で配合し たもの）を用いてモザイク状に積み重ねて作成された。 その手順を示寸と，モルタルブロックを打設後21時間 定経て脱型し, 約 1 個月の水中鉦生 (温度 $20^{\circ} \pm 1^{\circ} \mathrm{C}$ ) を行なった後, 2 日間恒温室 (温度 $20^{\circ} \pm 1^{\circ} \mathrm{C}$, 相対湿 度 $60 \pm 5 \%$ ) 湤置して乾燥させる。乾燥後ブロック 表面を金属ブラシを用いてレイタンスを取り除さ，型 わく内で $3 \mathrm{~mm}$ 間隔でモルタルブロックをモザイク状 に並べる，次に，セメントペーストの充てん物ををブ ロック間に流し込んで 2 日後に脱型した後, 2 日間の 水中盖生之 1 日間の恒温室内乾燥苞する。次化, 模型 の表面と裏面をみがいてアセトンで清浄した後, その 表面にアラルダイトDを用いて二軸型光弾性ひずみ計 を接着し，1日後その裏面に三軸型抵抗線ひずみ計抒 よび沈下測定用鋼棒を接着する。皇の1日後に載荷試 験を行なう。載荷試験は島津製リーレー式万能試験機 （容量 $100 \mathrm{t}$ ）使用して行ない, 載荷速度は約 $10 \mathrm{~kg}$ $/ \mathrm{cm}^{2} / \mathrm{min}$ である。な特, 載荷試験 $5 \sim 6$ 時間前飞特 殊アルミナセメントを用いて模型を剛な鋼板に設置し て和き，偏心の影響を軽隇させた。

応力測定々沈下測定は個々のブロックの中央点に特 いて, 各荷重段階ごとに二軸型光弾性ひずみ計と三軸 型抵抗線ひずみ計抢よびダイヤルダージにより行なっ た。

載荷は剛性載荷（剛な鋼板による載荷）とたわみ性 載荷（剛な鋼板の下㴟さ $7 \mathrm{~mm}$ のゴム板を置いて載 荷）の 2 種類により行ない, 載荷幅をブロック幅の 1 , 
2 および 3 倍の 3 種類に変化させた。

逐次破壊の状況は表面に現われるクラックを肉眼で 観察した.

\section{$3 \cdot 2$ 模型材料の性質}

$3 \cdot 2 \cdot 1$ セメントモルタルの性質 岩石のアナロ ジーとして使用したセメントモルタルの配合は，宇部 普通ポルトランドセメントと豊浦標準砂を重量比で 1 : 2 とし, 水セメント比を $60 \%$ とした. Table II に諸 性質を示す。

Table II. Properties of cement mortar.

\begin{tabular}{l|cc}
\hline Compressive strength & 305 & $\mathrm{~kg} / \mathrm{cm}^{2}$ \\
Tensile strength & $19.1 \mathrm{~kg} / \mathrm{cm}^{2}$ \\
Elastic modulus & $25000 \sim 28000 \mathrm{~kg} / \mathrm{cm}^{2}$ \\
Po1sson's ratio & $0.23 \sim 0.26$ \\
\hline
\end{tabular}

$3 \cdot 2 \cdot 2$ セメントペーストの性質 充てん物とし て使用したセメントペーストは次の 3 種類であり, そ の配合は宇部普通ポルトランドセメントと宇部ポゾラ ン（フライアシュ）を重量比で $1: 0$ (以下充てん物 1 とする)，1:1 (以下充てん物 2 とする) および $1: 2$ （以下充てん物 3 とする）とし，水セメント比を $60 \%$ とした. Table III に諸性質を示す.

Table III. Properties of cement paste used as filler.

\begin{tabular}{l|c|c|c}
\hline & $\begin{array}{c}\text { Strength of bending } \\
\text { moment }\left(\mathrm{kg} / \mathrm{cm}^{2}\right)\end{array}$ & $\begin{array}{c}\text { Compressive } \\
\text { strength }\left(\mathrm{kg} / \mathrm{cm}^{2}\right)\end{array}$ & $\begin{array}{r}\text { Elastic modulus } \\
\left(\mathrm{kg} / \mathrm{cm}^{2}\right)\end{array}$ \\
\hline F11ler 1 & 37.5 & 1538 & 35000 \\
F11ler 2 & 252 & 716 & 20000 \\
F11ler 3 & 156 & 31.4 & 12000 \\
\hline
\end{tabular}

\section{$3 \cdot 2 \cdot 3$ 不連続面のせん断強度 不連続性基盤の} 応力分布および破壊現象を定量的に考察するために, 不連続面のせん断強度を把握する必要がある. Fig. 3 に二面せん断試験の方法と結果を示す。ここでは簡単 にせん断強度は Coulombの直線式で表わされるとす る.

\section{$3 \cdot 3$ 実験結果および考察}

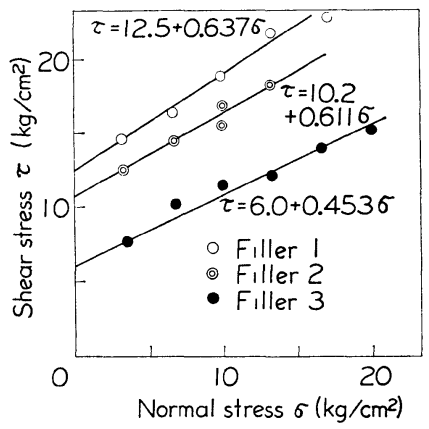

Fig. 3. Shear lines in two-section shearing test.
この種の不連続面を含む基盤の応力, 変形および破 壊は不連続面の性質一充てん物の性質, 荷重幅に対す る不連続面の大きさ・ひん度・方向性および含水状態 などーに強く影響される。

$3 \cdot 3 \cdot 1$ 充てん物の性質の影響 光弾性材料によ る模型実験により充てえ物の性質は基盤の応力および 変形に大きな影響を及ぼすことがわかっている。

Fig. 4 (a)，(b)，(c) はブロック幅 $C$ と荷重幅 $T$ との 比 $C / T$ が 1 である場合の充てん物 $1,2 ， 3$ を用いた 模型に打汁るそれぞれの逐次破壊状態を示す。これよ

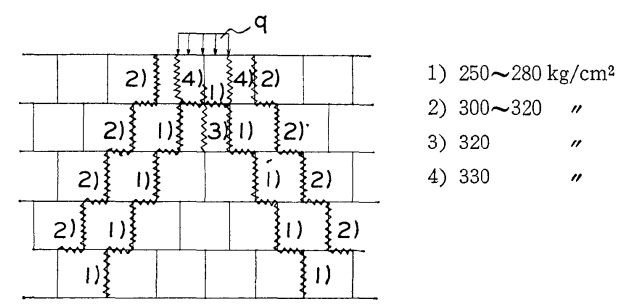

(a)

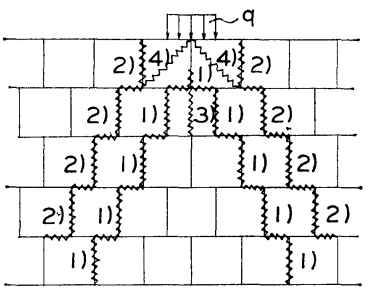

1) $160 \sim 200 \mathrm{~kg} / \mathrm{cm}^{2}$

2) $260 \sim 270$ "

3) 280

4) 300 "

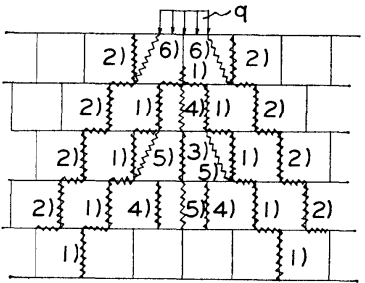

(c)
1) $80 \sim 100 \mathrm{~kg} / \mathrm{cm}^{2}$

2) $100 \sim 130 \quad$ "

3) 150 "

4) $200 \sim 230 \quad$ "

5) $250 \sim 280 \quad$ "

6) 320

Fig. 4. States of progressing fracture of discontinuous models for $C / T=1$ through rigid loading plate using (a) filler 1, (b) filler 2 , (c) filler 3.

り充てん物の強度が小さくなるにつれて初期クラック の発生する荷重が $250,160,80 \mathrm{~kg} / \mathrm{cm}^{2}$ としだいに下 がっているのがわかる。番た，クラックの発生は充て ん物 1 ではかなり大きな破壊音を伴らが，充てん物 2 抢よび 3 では臣とんど音もなく起こる.クラックの進 展する順序と最終的破壊強度 (モルタルブロックの破 壊強度に等しい）はいずれの場合においても活涪同様 であるが，弱い充てん物 3 の場合に沶いては載荷面直 下深部までクラックが進展する。ここで，1）のクラ ックは括もに引張りが支配的である破壊（以下局部引 張破壊と呼ぶ）により発生して下層へ進展したものと 
考光られ，2）のクラックは挑もにせん断が支配的で ある破壊（以下局部せん断破壊之呼ぶ）に上るものと 考觉られる。このことは後述する。

ここで林が考えているように，等方等質の弾性理論 より計算される応力によって不連続面のせん断破壊を 考光ると, 各充てん物 $1,2,3$ の場合に掠いて 2) の位置の第 1 層にそれぞれ $57,32,10 \mathrm{~kg} / \mathrm{cm}^{2}$ の非常 に低い荷重で初期クラックが生ずることになる。また この考光方では，1）のクラックを説明することはで きず，実験結果と相違する。これは等方等質の弾性理 論によって不連続面上の平均的垂直応力执よびせん断 応力を算出していること, 充てん物の存在とその変形 を考慮していないこと拉よび水平不連続面上のせん断 力を無視していることなどの問題点が考兄られ，この 種のある程度のせん断抵抗（付着抵抗と摩擦抵抗）を もつ充てん物を含む模型については不適当である.

次に応力は充てん物 1，2，3 と西初期クラックが 生ずる以前より載荷面直下に集中する現象を示し, 軟 弱な充てん物ほどその傾向は強い。また，荷重が増大 してクラックが進展すると、な就一層側方への分散が 少なくなりその傾向は強くなる．これは鉛直方向の主 弾性係数が水平方向のそれより大きい直交異方性基盤 の載荷面直下への応力集中現象之類似する。すなわち, 水平な不連続面と鉛直な不連続面は別な働き示する のと考学られる。 また, 荷重の增加とともに載荷面直 下のブロックに水平方向の引張主応力が認められてい るが，軟弱な不連続面活どその傾向は強い。こ机は層 自体がはりの挙動を示す曲げ引張りと回転したブロッ ク端による応力集中のためと考兄られる. 以上のこと は前の光弾性材料による実験でも認めらている.

したがって，この種の不連続性基盤に対する理論は 充てん物の性質一厚さ, 弾性あるいは粘弾性定数およ び強度一をなんらかの形で含んだものでなければなら ない。

$3 \cdot 3 \cdot 2$ 荷重幅の影響 構造物の大きさに対する 不連続面のひん度, すなわち荷重幅に対するブロック 幅の比 $C / T$ が变化した場合, 基盤の応力や破壊にぞ のような影響を及ぼすかについて若干の検討を行なう。 Fig. 5 (a)，(b) 飞充てん物 2 使用した $C / T=1 / 2,1 / 3$ の模型に打ける腩性載荷の場合の逐次破壞状態を示す。 ここで初期クラックが生ずる荷重を比べてみると, $C / T$ が $1,1 / 2,1 / 3$ と小さくなるに従ってそれぞれ 160, $130,100 \mathrm{~kg} / \mathrm{cm}^{2}$ とその荷重は小さくなっている. し かし, ここで注意しなければならない点は, 初期クラ ックの発生が局部せん断破壞によるものと局部引張破 壊によるものの 2 種類があるといらことである。した がって, まず局部せん断破壞淿よるクックの発生荷 重を考光ると， $C / T$ が $1,1 / 2,1 / 3$ 之小さくなるにつ

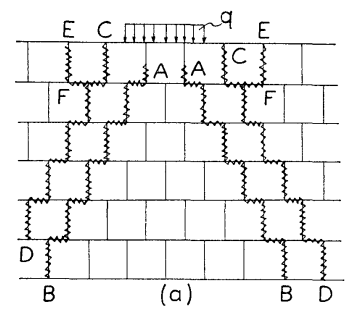

1) $\mathrm{CD} \quad 120 \sim 150 \mathrm{~kg} / \mathrm{cm}^{2}$

2) $\mathrm{AB} 200 \sim 220 "$

3) $\mathrm{EF} 210 \sim 230$ " Rupture 280 300 "
1) $\mathrm{AB} \quad 90 \sim 110 \mathrm{~kg} / \mathrm{cm}^{2}$

2) $\mathrm{CD} \quad 100 \sim 130 "$

3) $\mathrm{EF} 130 \sim 170$ " Rupture 280 300 "

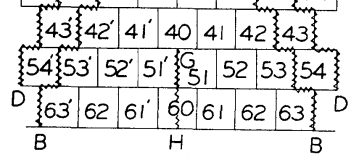

(b)

Fig. 5. States of progressing fracture of discontinuous models through rigid loading plate using filler 2 (a) for $C / T=1 / 2$, (b) for $C / T=1 / 3$.

れてそれぞれ $260,130,120 \mathrm{~kg} / \mathrm{cm}^{2}$ と小さくなって いる.これは $C / T$ が小さくなるにつれて局部せん断 クラックが生ずる位置のせん断力が大きくなることに よるものと考兄られる．次に局部引張破壊によるクラ ックの発生荷重を考光ると, $C / T$ が $1,1 / 2,1 / 3$ と小 さくなってもとれぞれ $160,210,100 \mathrm{~kg} / \mathrm{cm}^{2}$ と漸減 していない.これは $C / T$ が小さくなるにつれて局部 引張クラックが生ずる位置の局部せ九断力が大きくな る一方, ブロックの回転が少なくなり局部引張力が减 少するためと考兄らる。 また同じく $C / T$ が小さく なるにつ机て、この両者によるクラック発生荷重の差 異は少なくなり,かつ載荷面直下において深部までク ラックが発生することが認められる。

$C / T$ が $1 / 2,1 / 3$ の場合に荷重が増すにつれて Fig. 5

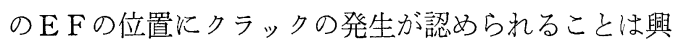
味深い。これはABあるいはCD拈けるクラックの 開口と沈下の増大に伴って，EF和汀る抵抗が減じ るためと考党られる。

$3 \cdot 3 \cdot 3$ 載荷板の剛度の影響 この種の不連続性 基盤の破壞, 応力抢よび変形の特性を $C / T=1 / 3$ の場 合の剛性載荷板を用いたものとたわ久性載荷板を用い たものの二つを対比しながら述べる.

（1）破壊状態: Fig. 5 (b), Fig. 6 は $C / T=1 / 3$ の場 合の剛性載荷およびたわみ性載荷に上る逐次破壊状態 を示す．剛性載荷による場合は，10回の同じ条件下の 実験汇沏いて第 1 番めのクラック（初期クラック）が 生ずる割合は $\mathrm{AB}, \mathrm{CD}, \mathrm{EF}, \mathrm{GH}$ 飞沿う不連続面に それぞれ60，10，10，20\%であり，第 2 番めのクラッ ク（第2クラック）が生ずる割合はそれぞれ 20,50 , 30，0\%である。これょりAB沿ら不連続面に最も 


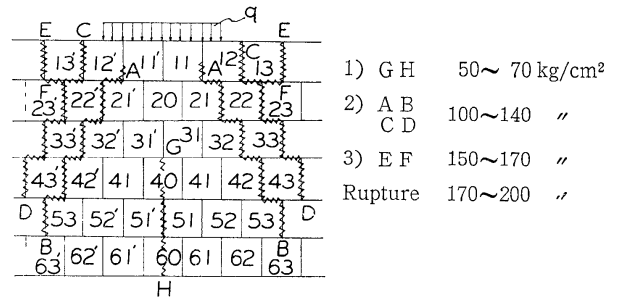

Fig. 6. States of progressing fracture of discontinuons models through flexible loading plate using filler 2 for $C / T=1 / 3$

クラックが発生しやすく, 次いで C D 沿ら不連続面 にクラックが発生しやすいことがわかる。これらのク ラックは，AB沿う場合はA 始まる局部引張破壊 が，CD沿ら場合はC 亿始まる局部せん断破壞がそ れぞれ支配的であり，その後ブロックの回転やクラッ ク先端唀発される局部引張破壞が加味されて下層に クラックが進展していくものと考兄らるる。た， G Hに沿ら不連続面にクラックが発生するのは, 載荷面

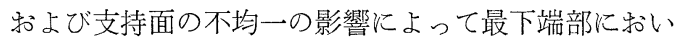
て曲げ引張りが生ずるためと考光られる。次に，たわ み性載荷による場合は, 剛性載荷に比べて非常低い 荷重 $\left(50 \sim 70 \mathrm{~kg} / \mathrm{cm}^{2}\right)$ で GHV沿ら不連続面化初期 クラックが発生する割合が全実験（5 回）の80\%と圧 倒的渂高く, これは後述するように, たわ性載荷に より載荷面直下への応力集中度が高いことから, 支持 面での曲げ弓張りを誘発する可能性が強いためである と考光られる.しかし, 全体としてはりの挙動を示さ ない滦ど模型の深さが充分ある場合においてはこのよ らな現象は起きないだろらし，事実 $1 \mathrm{~cm}^{3}$ の小さな モルタルブロックを同様に13層積又重㸚た実験沈いい ては認められなかった。次いで, A B 特よび C D た 沿ら不連続面にクラックが泳ぼ同じ荷重で発生するが， これは後述するように剛性載荷に比べて鉛直応力が載 荷中心部に集中する傾向を示すので, ブロック12の回 転が少なくなってA扎打る引張力が小さくなり, 局 部引張破壞がいくぶん抑制されるためと考光られる。 また, 終局破壊強度がたわ性載荷の場合は $200 \mathrm{~kg} /$ $\mathrm{cm}^{2}$ 之剛性載荷の場合の $300 \mathrm{~kg} / \mathrm{cm}^{2}$ より低い值を示 すが，これはブロックが奥行き方向に割裂するためで ある。

(2)応力状態：Fig. 7 (a)，(b)《剛性載荷抒よびたわみ 性載何による荷重と鉛直応力の関係を示す。な抗ここ では,ブロック中央点で測定したひずみより算出した 鉛直応力の值をブロック内では一様に分布するとして 示している. 光弾性ひずみ計に現われるしま模様は, 丹羽らによって考光られた理論的解析法に従って解析 したが，モルタルの絶対ひずみが小さく㐫りり高い精

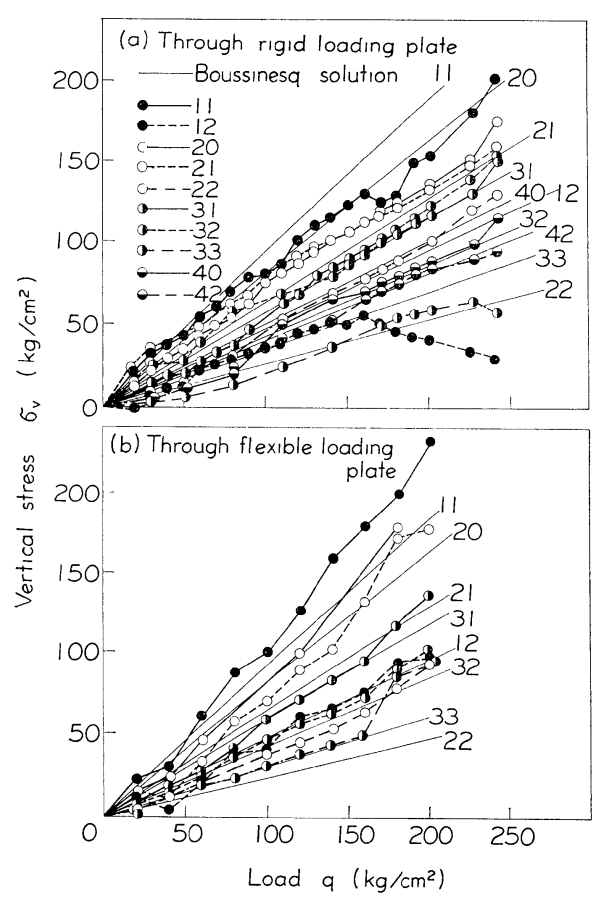

F1g. 7. Relation between load $q$ and vertical stress $\sigma_{v}$.

度は期待されないので, 補足的に利用することに止め た。これとよると, 剛性載荷の場合飞第 1 層の載荷面 直下のブロック $11,11^{\prime}, 12,12^{\prime}$ 亿括汗る鉛直応力の 総和はまだクラックが発生していない荷重 $100 \mathrm{~kg} / \mathrm{cm}^{2}$ 付近ではその約 $85 \%$ てかならず, Boussinesq の解 の約 $88 \%$ と比べて少ない。これは Krsmanović らの実 験にも見られるように, 剛性載荷板の影響により載荷 中心線より荷重幅の $1 / 3$ だけ左右にずれた位置，すな わち著者らの実験の場合には不連続面付近飞鉛直応力 が集中し, 不連続面はもとより1個のブロック内であ っても鉛直応力は一樣に分布していないことによる。 この事実は第 2,3 層の鉛直応力分布から容易に推測 される．したがって，このことを考虑に入れると，荷 重の大部分は載荷面直下の四つのブロックに分布され て技り，それより側方への分散はほとんどないと言光 る. 次化, 第 2 層と第 3 層に打いては剛性載荷板の影 響により載荷中心線より左右にずれた位置, すなおち $21 ， 21^{\prime} ， 32 ， 32^{\prime}$ のブロックに鉛直応力が集中してい るとともに, 荷重 $100 \mathrm{~kg} / \mathrm{cm}^{2}$ 付近なではCDの不連 続面の内側にある載荷面直下のブロックに怙いて鉛直 応力の総和は載荷重の $90 \sim 95 \%$ を占めている。しかし， 荷重の増大とクラックの発生に伴って載荷中心部への 鉊直応力集中の変化が現われる. 特に, 荷重が 150 $\mathrm{kg} / \mathrm{cm}^{2}$ 付近での局部破壞の急激な進行に伴い上層部 に拉ける変化が著しく, 載荷中心部のブロック11，20 に称いて曲線のこう配すなわち応力増加率が大きくな 
るが，12のブロックでは逆に応力は減少している．た わみ性載荷の場合は, 剛性載荷の場合に比べて載荷中 心部への鉛直応力集中の傾向は著しい，その集中度は 第1 層飞扮いては荷重60, $120,180 \mathrm{~kg} / \mathrm{cm}^{2}$ 飞対して それぞれ86，100，105\%を示し，第2 層においてはそ れぞれ 83，99，121\%を示すよらに剛性載荷の場合と 同樣に荷重の增大とともに中央部への集中度は増す. また, 載荷中心線上の鉛直応力が第 1 層抢よび第 2 層 に牧いて荷重の約1.0 1.2倍の值を示しているが，こ れは林の考光ている複合パスカル分布と汇泣一致する。 しかし，Krsmanović らの実験に示される荷重幅の 0.667 倍の深さで荷重の2.6倍もの集中度は認められな い.

Fig. 8(a)，(b)に破壊が相当に進行した状態の剛性載 荷和よびたわ及性載荷による主応力の大きさと方向を 示与. 剛性載荷の場合において, 主応力方向は載荷中 心線近くのブロックでは Boussinesq の解よりも鉛直

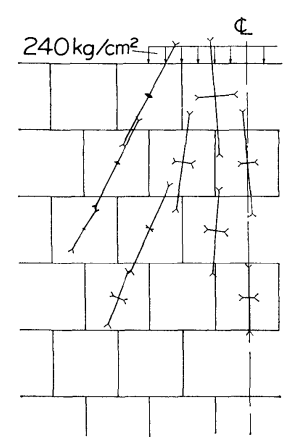

(a)

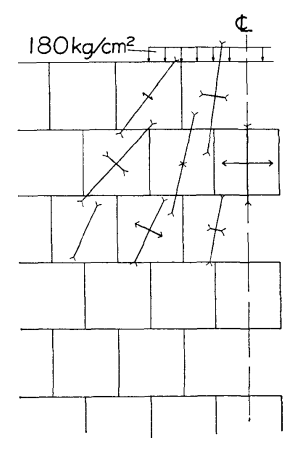

(b)
Through (a) rigid loading plate, (b) flexıble loading plate.

Fig. 8. Direction and magnitude of principal stresses.

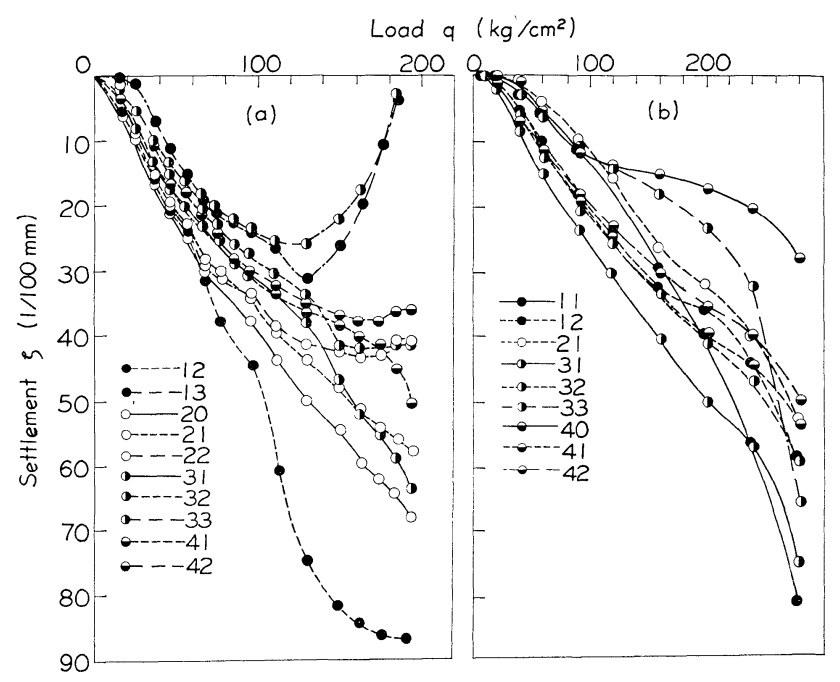

Through (a) rigıd loading plate, (b) flexıble loadıng plate. Fig. 9. Relation between load $q$ and settlement $\zeta$.
方向に近く，荷重の増大とともに上層部のブロックに 抢いてその傾向は強くなる。これは前述の載荷中心部 への鉛直応力集中の変化と一致する。また引張主応力 の発生が認められる。たわ性載荷の場合飞沶いても， 同様汇載荷中心線近くの上層部ブロックで主応力方向 は鉛直方向に近くなるとともに, 引張主応力の発生領 域も広範囲となる。

(3)変形状態：Fig. 9 (a)，(b)飞剛性載荷およびたわみ 性載荷による荷重一沈下曲線を示す。剛性載荷の場合 飞招いては, 荷重の增大に伴い初めは沈下は直線的に 增加するが，荷重が $60 \mathrm{~kg} / \mathrm{cm}^{2}$ をこえるあたりからそ のこう配は小さくなっている。これは充てん物の応力 一ひずみ関係の非線型比よるもので, 压縮されて弾性 係数が增大するためと考光られる.ささら、クラック が盛ん進展する荷重 130 ～140 $\mathrm{kg} / \mathrm{cm}^{2}$ で曲線のこう 配すなおち沈下の增加率にかなりの変化が生ずる。す なわち, 載荷中心線近くのブロック20，31，41では沈 下の增加率は大きくなり，その隣りのブロック12,21, 22，32，42では沈下の增加率は小さくなり, ブロック 13，33では逆に沈下の回復が認められる。これらの現 象は, 載荷中心部への応力集中の変化之載荷中心線よ り離れたブロックの回転などより説明される。な挔， 浮上りの現象は君島らの実験机いても認められる。 次に，たわ性載荷の場合に括いては，荷重 70〜80 $\mathrm{kg} / \mathrm{cm}^{2}$ で上層部の載荷中心線近くの沈下の増加率は わずかと大きくなる。これは上層部での載荷中心部へ の応力集中尤るものと考光られる，また，荷重が増 大して終局破壊荷重に近くなると, 各ブロックの沈下 の增加率は全般に大きくなる傾向を示し，この場合は 沈下の回復現象は認められなかった。

\section{4 結言}

本研究は従来のこの種の模型を用いた研 究と異なり，不連続面に充てん物をてん充 してこの充てん物が不連続性基盤の応力, 変形抢よび破壊状態仅ぼす影響について 考察を加光るとともに，理論的解析への手 がかりを与克た，実験結果を要約すると次 のようである。

（1）軟弱な不連続面を含む基盤は，不連 続面上での局部破壊によるクラックが発生 する以前より, 載荷面直下への鉛直応力集 中の現象を示し,クラックの進展によりな おいっそうその傾向を強くする。

（2）局部破壊には局部引張破壞と局部せ 几断破壊の二つが考兄られ，C/T が小さ

*1 君島博次, 若本 清, 第 1 回岩盤力学シンポジ ウム (1962) 
くなるにつれて両者によるクラック発生荷重は近くな る.

（3）剛性載荷の場合の鉛直応力は，載荷中心線より 多少左右にずれた位置に集中する。また, 荷重の増大 に伴い応力集中の位置は中心線のほうに移動するとと も注, 載荷面直下に引張主応力が発生する。 たわ久性 載荷の場合の鉛直応力は載荷中心線近くに集中し, 荷 重の増大に伴いその傾向は增すとともに, 載荷面直下 の引張主応力の発生領域も広い.

（4）荷重一沈下曲線は不連続面に括活る充て儿物の 応力一びずみ関係の非線型性により, 荷重の増大とク ラックの進展に伴い載荷中心線近くで沈下の增加率を 大きくし，中心線より離れたところで沈下の増加率を 小さくし, 剛性載荷の場合に沶いては沈下の回復現象 をも示す。

（5）初期クラックの発生後, クラックは階段状に下 層へ進展するが, こ扎は不連続面の性質（厚さ，弾性 あるいは粘弾性定数および強度), 不連続面での変形
によるブロックの移動（回転拉よび平行移動）および クラック先端に誘発される局部引張破壊について考虑 する必要がある。

この不連続性基盤に適用すべき理論的解析法につい ては後の機会に発表したい。

最後に, 本研究を行ならに際して終始ご指導くださ った京都大学工学部丹羽義次教授, 同赤井浩一教授, 実験に協力してくださった鹿島建設村田睟昭氏の各位 に感謝の意を表する。

(昭和 42 年 5 月 28 日 土不学会年次学術講寅会飞て講演)

\section{参 考 文 献}

1) Krsmanović, D., and S., Milić, Rock Mech. and Eng. Geol, Suppl. I, 72 (1964).

2) Trollope, B.H., and E. T. Brown, Water Power, 17, 310 (1965).

3）林正夫, 電研技術研究所報告, 土木63011 (1963).

4) 丹羽義次, 小林昭一, 平島健一, 材料, 17, 933 (1968). 